\author{
Мангура Л. П., здобувач \\ (науковий керівник - доктор сільськогосподарських наук В. П. Рибалко) \\ Полтавська державна аграрна академія
}

\title{
ПРОДУКТИВНІ ЯКОСТІ СВИНЕЙ ЧЕРВОНОЇ БІЛОПОЯСОЇ ТА ВЕЛИКОЇ БІЛОЇ ПОРІД ЗА РІЗНИХ МЕТОДІВ РОЗВЕДЕННЯ
}

\section{Рецензент - кандидат сільськогосподарських наук Н. Д. Голуб}

Наведені результати продуктивних якостей червоної білопоясої (ЧБП) та великої білої (ВБ) порід свиней за рещипрокного схрещування. Встановлено, щуо найбільш багатоплідними (10,91 поросяти) виявилися свиноматки ВБ породи за чистопородного розведення. У схрещуванні багатопліднішими (10,82 поросяти) були поєднання ВБ × ЧБП; була найвищою й жива маса гнізда поросят $(169,83)$ у час відлучення у 60 днів. Жива маса кожного відлучника найбільшою (17,61 кг) виявилась у чистопородних білопоясих поросят. Схрещування маток ВБ із кнурами ЧБП порід сприяло більш інтенсивному росту помісного молодняку за меншої витрати корму на кожний кілограм nриросту.

Ключові слова: порода, помісі, підсвинки, свиноматки, гібридизаиія, багатоплідність .

Постановка проблеми. Останні роки проводилася значна кількість досліджень з удосконалення існуючих та створення нових спеціалізованих ліній, типів і порід свиней на внутрішньопородній, а також міжпородніх основах із метою подальшого їх використання у різних варіантах схрещування, породно-лінійної та міжлінійної гібридизації. Однак, для практичного використання їх необхідно попередньо перевірити на взаємну поєднаність.

Останне особливо актуальне, поскільки нині свиней розводять у господарствах різних за розміром, формою власності, наявності умов годівлі та утримання. Власне, навіть у межах однієї природно-кліматичної зони свині окремих генотипів різняться між собою за біологічними і господарськи корисними ознаками. Тому вивчення нової червоної білопоясої породи в різних поєднаннях $\epsilon$ наразі актуальним $\mathrm{i}$ має науковопрактичне значення.

Аналіз основних досліджень і публікацій, у яких започатковано розв'язання проблеми. У процесі створення ЧБП породи окремими вченими проводилися дослідження на поєднаність даного генотипу з іншими породами.

Так, Фесенко О. Г. у своїх дослідженнях довела, що за поєднання червоно-поясої спеціалізо- ваної лінії м'ясних свиней (нині - порода ЧБП) із полтавською м'ясною (ПМ) породою матки відрізнилися більшою великоплідністю $(1,26$ кг) й масою одного поросяти в час відлучення у 45 днів $(14,0$ кг) порівняно 3 аналогами великої білої породи. У дослідженнях С. М. Галімова - за схрещування ЧБП породи 3 ландрасом (Л) встановлена великоплідність 1,58 кг, де материнською формою виступала червона білопояса порода, а батьківською - ландрас, що переважало середні дані по стаду господарства на 12 [1-5].

Мета досліджень. Метою даної роботи $\epsilon$ аналітичне визначення основних методичних підходів у процесі створення червоної білопоясої популяції м'ясних свиней, а також вивчення ефективності ії̈ використання за розведення «в собі» $\mathrm{i}$ в різних поєднаннях із найбільш розповсюдженою великою білою породою свиней за різних рівнів годівлі.

Завдання: визначити репродуктивні, відгодівельні й м'ясо-сальні якості свиней червоної білопоясої породи з великою білою за реципрокного схрещування та провести порівняльне вивчення окремих господарських i біологічних особливостей одержаного молодняку різного походження за використання на відгодівлі повноцінних комбікормів за існуючими нормами $\mathrm{i}$ досхочу.

Методи дослідження. У роботі використані загальноприйняті методи, зокрема: історичнонауковий, популяційний, зоотехнічний, фізіологічний, біохімічний, економічний та біометричний метод досліджень із застосуванням обчислювальної техніки.

Результати досліджень. Як видно 3 даних таблиці 1 , найвищими показниками багатоплідності характеризувалися матки великої білої по-

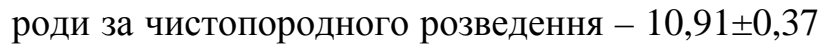
голови. Найбільшою масою гнізда поросят у 60 днів були матки II (ВБхЧБП) піддослідної групи $169,83 \pm 4,82$ кг, а масою кожного поросяти в час відлучення 17,61 $\pm 0,15$ кг - свиноматки червоної білопоясої породи (IV група). 
СТОРІНКА МОЛОДОГО ВЧЕНОГО

\section{1. Репродуктивні якості піддослідних свиноматок}

\begin{tabular}{|c|c|c|c|c|c|}
\hline $\begin{array}{l}\text { Піддослідні } \\
\text { групи }\end{array}$ & $\begin{array}{l}\text { Багатоплідність } \\
\text { свиноматок, гол. }\end{array}$ & $\begin{array}{c}\text { Великоплідність, } \\
\text { кг }\end{array}$ & $\begin{array}{c}\text { Маса гнізда в час } \\
\text { відлучення, кг }\end{array}$ & $\begin{array}{l}\text { Маса одного } \\
\text { поросяти, кг }\end{array}$ & 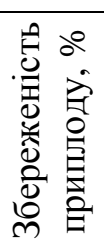 \\
\hline I (контрольна) & $10,91 \pm 0,37$ & $1,06 \pm 0,006$ & $155,10 \pm 3,86$ & $16,19 \pm 0,16$ & 89,6 \\
\hline II & $10,82 \pm 0,32$ & $1,09 \pm 0,016$ & $169,83 \pm 4,82 *$ & $17,28 \pm 0,17$ & 91,7 \\
\hline III & $10,40 \pm 0,38$ & $1,19 \pm 0,012^{*}$ & $163,47 \pm 2,46^{*}$ & $17,30 \pm 0,03$ & 92,5 \\
\hline IV & $9,82 \pm 0,38$ & $1,20 \pm 0,017$ & $160,15 \pm 5,03$ & $17,61 \pm 0,15$ & 94,9 \\
\hline
\end{tabular}

* $\mathrm{P}<0,05$ - різниця порівняно 3 першою піддослідною групою

\section{2. Відгодівельні якості молодняку свиней}

\begin{tabular}{|c|c|c|c|c|}
\hline \multirow[b]{2}{*}{ Піддослідні групи } & \multirow[b]{2}{*}{ Поєднання } & \multicolumn{3}{|c|}{ Годівля за нормами } \\
\hline & & $\begin{array}{c}\text { вік досягнення } \\
100 \text { кг, дні }\end{array}$ & $\begin{array}{c}\text { середньодобові } \\
\text { прирости, г }\end{array}$ & $\begin{array}{c}\text { витрати корму, } \\
\text { корм. од. }\end{array}$ \\
\hline I (контрольна) & ВБ $\times$ ВБ & $202,4 \pm 1,37$ & $631,75 \pm 8,15$ & 4,29 \\
\hline II & ВБ×ЧБП & $193,4 \pm 1,21$ & $687,83 \pm 4,16$ & 3,99 \\
\hline III & ЧБП×ВБ & $196,8 \pm 1,13$ & $664,25 \pm 7,49$ & 4,12 \\
\hline IV & ЧБП×ЧБП & $194,3 \pm 1,50$ & $694,33 \pm 8,28$ & 3,93 \\
\hline \multirow[b]{2}{*}{ Піддослідні групи } & \multirow[b]{2}{*}{ поєднання } & \multicolumn{3}{|c|}{ Годівля досхочу } \\
\hline & & $\begin{array}{c}\text { вік досягнення } \\
100 \text { кг, днів }\end{array}$ & $\begin{array}{c}\text { середньодобові } \\
\text { прирости, г }\end{array}$ & $\begin{array}{c}\text { витрати корму, } \\
\text { корм. од. }\end{array}$ \\
\hline I (контрольна) & $\mathrm{BБ} \times \mathrm{BБ}$ & $192,7 \pm 1,47$ & $688,58 \pm 8,92$ & 4,05 \\
\hline II & ВБ×ЧБП & $182,50 \pm 1,23$ & $744,83 \pm 4,70$ & 3,75 \\
\hline III & ЧБП×ВБ & $184,8 \pm 0,46$ & $724,83 * \pm 11,33$ & 3,88 \\
\hline IV & ЧБП×ЧБП & $185,9 \pm 1,29$ & $715,8 \pm 9,94$ & 3,87 \\
\hline
\end{tabular}

Найвищою збереженість $(94,9 \%)$ виявилася у маток червоної білопоясої породи за чистопородного розведення. Як свідчать дані таблиці 2 , у разі нормованої годівлі кращими показниками характеризувалися помісі та їх аналоги IV (ЧБПхЧБП) піддослідної групи. Аналогічна тенденція щодо відгодівельних якостей збереглася й у випадку відгодівлі тварин досхочу.

За нормованої годівлі різниця між тваринами контрольної та дослідних груп за показниками забійного виходу, довжини туші, товщини шпику на рівні 6/7 грудних хребців, площею «м'язового вічка» i масою задньої третини напівтуші коливалися, відповідно, в межах: 0,3$0,25 \%$; $0,0-1,3 \mathrm{~cm} ; 1,3-1,8 \mathrm{~mm} ; 3,0-4,5 \mathrm{~cm}^{2}$ i $0,25-$ 0,40 кілограма. За морфологічним складом туш найбільш м'ясними виявилися свині, отримані від ЧБП породи, а також помісі II і III піддослідних груп. У разі годівлі свиней досхочу суттєвої різниці за відгодівельними якостями між молодняком піддослідних груп не спостерігалося, однак збереглася тенденція переваги генотипу ВБ×ЧБП над їх аналогами I групи.
Як показали фізико-хімічні дослідження, м'ясо підсвинків II і IV піддослідних груп у порівнянні 3 м'ясом аналогів I і III груп мало на 5,0-9,3\% меншу енергетичну цінність, що є характерним для пісної свинини.

Методами зоотехнічної та економічної оцінок встановлено, що незалежно від рівня годівлі найбільш низькою собівартістю 1 центнера приросту характеризувалися помісні підсвинки. Аналогічні результати були отримані й у дослідженнях інших авторів [2-5].

Висновки. Отримані експериментальні дані, а також їх статистична обробка дають можливість зробити наступні висновки:

1. Схрещування свиней великої білої породи 3 червоною білопоясою сприяє більш інтенсивному росту й покращанню якості отриманого приплоду.

2. Економічна оцінка досліджень показала, що рівень рентабельності відгодівлі помісного молодняку становив 21,90-22,15 \%, тоді як по контрольній групі цей показник дорівнював лише 18,9 відсотка. 


\section{БІБЛІОГРАФІЯ}

1. Волошук В. М. Тенденции, современное состояние и стратегия ведения свиноводства в Украине / В. П. Рыбалко // Инновационные пути разведения АПК: Проблемы и перспективы. Персиановка. - 2013. - С. 26-30.

2. Галимов С. М. Воспроизводительные качества свиней красной белопоясой породи при чистопородном разведении и скрещивании / С. М. Галимов // Вісник Полтавської державної аграрної академії. - Полтава, 2007. - №4. C. 95-96.
3. Сердюк О. Г. Репродуктивные качества свиней специализированной мясной линии / О. Г. Сердюк // Зоотения, 1990. - №9. - С. 64-65.

4. Томін $€ . \Phi$. Відгодівельні якості свиней великої білої породи за різних методів розведення / Є. Ф. Томін // Вісник аграрних наук. - 2007. №10. - C. 80-82.

5. Фесенко О. Г. Забійні та м'ясо-сальні якості свиней різного напрямку продуктивності / О. Г. Фесенко // Вісник Полтавської державної аграрної академії. - 2003. - №6. - С. 109-110. 